\title{
UDC 614.8
}

Y.A. Abramov, Dr. Sc. (Tech.), Prof., orcid.org/0000-0001-7901-3768,

O. E. Basmanov, Dr. Sc. (Tech.), Prof., orcid.org/0000-0002-6434-6575,

J. Salamov, orcid.org/0000-0003-3583-9618, A. A. Mikhayluk, Cand. Sc. (Tech.), Senior Research

Fellow,

orcid.org/0000-0002-4116-164X

\section{MODEL OF THERMAL EFFECT OF FIRE WITHIN A DIKE ON THE OIL TANK}

Purpose. Building a mathematical model for the heat build-up in the oil tank shell under the thermal effect of a combustible liquid pool fire within the tank dike.

Methodology. A thermal balance equation for an oil tank exposed to heat from the pool fire has been worked out. Both radiant and convective heat transfer processes between the pool fire and the environment have been taken into account. Estimates for the distribution of temperatures and airflow velocities in the plume above the fire have been used to account for the convection component of the heat flux from the pool fire.

Findings. Dynamics of the tank shell temperature change in time under the thermal effect of the pool fire within the dike has been obtained. The obtained expression is the solution of the differential equation worked out on the basis of the thermal balance analysis for the oil tank shell exposed to heat.

Originality. The convective component of the heat flux from the pool fire to the oil tank is taken into account and estimates of the distribution of temperatures and velocities in the plume are built.

Practical value. The proposed model of the tank shell heat exposure to the pool fire within the dike could provide the basis for building a decision-making system for the fire response manager, outlining safe zones for positioning the equipment and personnel involved in fire-fighting, while developing fire pre-plans at the oil refining facilities and designing security systems for oil tanks.

Keywords: pool fire, oil tank, dike, combustible liquid, heat transfer, convection, radiant heat

Introduction. The pool fire of combustible liquid within the dike of the tank is one of the most dangerous situations for an oil depot. The heat flux from the combustion to the tank can lead to heating of the tank elements to the ignition temperature of petroleum vapors. Such heat exposure carries a threat of explosion of the vapor-air mixture in the gas space of the tank, posing danger to the personnel of the fire-fighting and rescue units involved in the fire response operations as well as to the technical personnel of the oil depot. In addition, the containment failure of the tank could lead to the heavy spill of the fuel into the combustion and an increase of the fire area.

Unsolved aspects of the problem. Each tank is equipped with a cooling system that supplies water to the outer surface of the tank shell. However, such systems are normally designed to protect against the heat flux from a fire at another tank. In the case when the combustion zone is located in the immediate vicinity, i.e. within the dike of the tank itself, such a cooling system may not be sufficiently effective. Heating of the tank shell portion above the level of the fuel (the so-called "dry shell") poses a particular danger, because it has no contact with the liquid and does not benefit from its cooling effect. Therefore, the priority task of the firefighting units arriving at the site of the fire is the cooling of tanks adjacent to the fire. For the safe positioning of the equipment and personnel involved in the fire re-

(C) Abramov Y.A., Basmanov O. E., Salamov J., Mikhayluk A.A., 2018 sponse operation, it is necessary to have estimates of the thermal effect of the fire on adjacent oil tanks.

Analysis of the recent research and publications. Radiant heat is the main type of heat transfer from an open pool fire to surrounding objects. Therefore, this type of heat transfer receives most attention. In the experiment [1], the radiant heat from the flames of combustible and flammable liquids is studied depending on the type of liquid and the diameter of the spill. In [2], additionally, the absorption of radiant heat by combustible liquid vapors and particles of smoke is taken into account. Determining the safety distance from the pool fire is considered in [3]. Such researches were conducted also for justification of the lengths for unboundaries systems [4, 5]. The radiant heat from continuous spill fires is studied in [6]. The model of the thermal effect of the fire in an oil tank on the adjacent tank is built in [7], taking radiant heat into account. In [8] the model of radiant heat from a fire is used to determine the fire resistance of the tank. The location of the combustion in the upper part of the tank causes the heat transfer to the neighboring tanks to occur only through radiation, eliminating the convective component. In [9], models of the thermal effect of a pool fire within a dike on the tank are considered; however, they do not take into account the convective plumes that rise over the combustion. In [10], a model has been developed describing the dynamics of temperature change in the tank shell during a fire in an oil depot which takes into account the inclination of the 
flame by the wind; however, only the radiant component of the heat flux from the fire has been taken into account. The regulatory documents relied on by the fire response managers are also based on the case of the fire within the tank [11]. The influence of wind on the spread of smoke from burning crude oil is studied in [12].

Previously unsolved part of the general problem. Existing models of the thermal effect of a pool fire on the oil tank do not take into account the convective component of the heat flux from the combustion to the tank. At the same time, if the oil spill is close enough to the tank, the contribution of the convective component can be significant.

Objectives of the article. The objective of this research is to construct a model of the oil tank shell heating under the thermal effect of a pool fire from a combustible liquid spill within the tank dike, taking into account the heat transfer both from the radiant and convective components.

Explanation of scientific results. When building the model of the oil tank thermal exposure, we shall proceed from the following assumptions.

1. The heat transfer from the combustible liquid flame is carried to the tank shell by radiation from the flame surface in accordance with the Stefan-Boltzmann law

$$
q_{i}=c_{0} \varepsilon_{s} \varepsilon_{w}\left(\left(\frac{T_{s}}{100}\right)^{4}-\left(\frac{T_{w}}{100}\right)^{4}\right) \psi,
$$

where $c_{0}=5.67 \frac{W}{m^{2} K^{4}}$ is a constant; $\varepsilon_{s}, \varepsilon_{w}$ are the degrees of thermal emissivity of the flame and surface element; $T_{s}, T_{w}$ are the temperatures of the radiating surface of the flame and of the surface element, respective$1 \mathrm{y} ; \psi$ is the view factor.

2. The shell is involved in the convective heat transfer with the combustion gases and the plume of heated air rising above the combustion according to Newton's law.

$$
q_{c}=\alpha\left(T_{f}-T_{w}\right),
$$

where $\alpha$ is the convective heat transfer coefficient; $T_{f}$ is the temperature of the airflow in contact with the tank.

3 . The dry shell of the tank heats up and then transfers heat to the environment and inside the tank.

4. The dry shell of the tank is involved in the convective heat transfer with a vapor-air mixture inside the tank's gas space. The temperature of the vapor-air mixture is equal to the ambient temperature.

5. The temperature of the tank shell is consistent through its thickness.

6. The thermal conductivity of the shell in the longitudinal direction does not affect the distribution of temperatures along it.

The assumption (5) is based on the results presented in [8], which shows that the temperature of the dry shell heated under the effect of the fire is almost the same throughout the thickness - the temperature difference between the outer and inner surfaces does not exceed $1.0 \mathrm{~K}$.

Assumption (6) is based on the results of calculations [7], which indicate that the areas on the tank shell lo- cated at a distance of $30 \mathrm{~cm}$ are practically thermally insulated from each other. In particular, the cooling effect of the liquid in the tank does not extend more than $30 \mathrm{~cm}$ above its level.

To build a mathematical model of the thermal effect of the pool fire within the dike on the dry shell of the tank, taking into account the convective effect of the fire plume, let us consider a surface element $\Delta$ with the area $S$ on the dry shell of the oil tank. It is involved in the following types of heat transfer (Fig. 1):

1. Radiant heat transfer from the flame $-q_{1}$.

2. Convective heat transfer from the fire plume $-q_{2}$.

3. Radiant heat transfer with the environment $-q_{3}$.

4. Radiant heat transfer with the tank interior $-q_{4}$.

5. Convective heat transfer with vapor-air mixture in the tank's gas space $-q_{5}$.

In accordance with the Stefan-Boltzmann law, the heat flux density of the flame radiant heat is determined by the formula (1), where

$$
\psi=\frac{1}{\pi} \iint_{S} \frac{\left(\vec{r}, \vec{n}_{s}\right)(\vec{r}, \vec{n})}{r^{4}} d S,
$$

where $S$ is the surface of the flame; $\vec{r}$ is the position vector connecting points on the surface of the flame and surface element; $\vec{n}_{s}, \vec{n}$ are unit normal vectors to the surfaces of the flame and surface element, respectively. In this case, the integral is taken only for those points of the surface $S$, where the position vector forms an acute angle both with the normal vector $\vec{n}_{s}$, and normal vector $\vec{n}$, i. e., both scalar products in the numerator of the integral (3) are positive.

According to Newton's law (2), the density of the heat flux to the surface element through the convective heat transfer from the plume flows rising above the combustion is equal to

$$
q_{2}=\alpha_{2}\left(T_{f}-T_{w}\right),
$$

where $\alpha_{2}$ is the coefficient of convective heat transfer. Depending on the distance between the combustion and the surface element $\Delta$ as well as the direction and speed of the wind, both $T_{f} \geq T_{w}$ and $T_{f} \leq T_{w}$ are possible. In the first case, the surface element would receive heat from the air stream $\left(q_{2} \geq 0\right)$, and in the second one it would give up heat $\left(q_{2} \leq 0\right)$.

Since the view factor of the surface element with the whole environment (including the flame) is equal to 1 , the density of radiant heat flux to the environment,

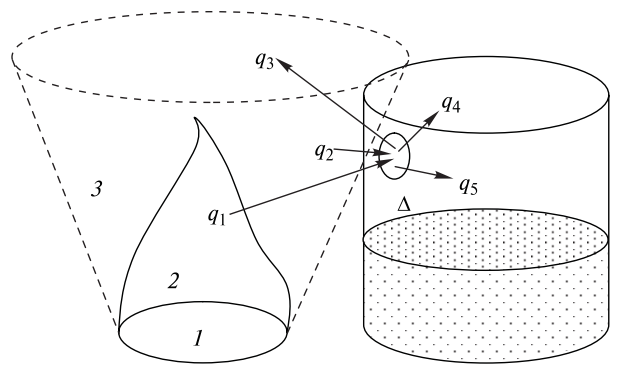

Fig. 1. Heat transfer of the tank shell in case of the fire within the dike:

1 -spill; 2 - flame; 3 - plume above the combustion 
without taking into account the flame, is

$$
q_{3}=c_{0} \varepsilon_{w}\left[\left(\frac{T_{0}}{100}\right)^{4}-\left(\frac{T_{w}}{100}\right)^{4}\right](1-\psi),
$$

where $T_{0}$ is the ambient temperature.

The internal surface of the surface element is involved in the radiant heat transfer to the surface of the fuel, the shell and the roof of the tank. Taking the thermal emissivity of the fuel surface as approximately equal to the thermal emissivity of the shell, we obtain the density of the radiant heat flux from the surface element to the shell and the roof of the tank, and to the surface of the fuel

$$
q_{4}=c_{0} \varepsilon_{w}^{2}\left[\left(\frac{T_{0}}{100}\right)^{4}-\left(\frac{T_{w}}{100}\right)^{4}\right],
$$

where the view factor for the above-mentioned surfaces equals 1, and the temperature of these surfaces is assumed to be equal to the ambient temperature.

The density of the heat flux due to convective heat transfer to the vapor-air mixture in the gas space of the tank is equal to

$$
q_{5}=\alpha_{5}\left(T_{0}-T_{w}\right),
$$

where $\alpha_{5}$ is the coefficient of convective heat transfer.

The density of the total heat flux to the surface element is expressed as

$$
q=q_{1}+q_{2}+q_{3}+q_{4}+q_{5}
$$

where $q_{1}>0, q_{3}<0, q_{4}<0, q_{5}<0 ; q_{2}$ could assume both negative and positive values depending on the temperature of the surface element, the location of the combustion, the direction and speed of the wind.

The total amount of heat received by the area $\Delta$ over a period of time $d t$ goes into its heating to the temperature $d T_{w}$

$$
q S d t=m c d T_{w}=\rho V c d T_{w}=\rho S \delta c d T_{w},
$$

where $m, V$ are mass and volume of the tank shell within the surface element $\Delta ; \delta$ is the tank shell thickness; $\rho, c$ are the density and heat capacity of the shell material (steel).

Thus, the dynamics of the surface element temperature change $\Delta$ is described by the following differential equation

$$
\frac{d T_{w}}{d t}=\frac{q}{\rho \delta c} .
$$

By combining $(1,4-8)$ and substituting them into (9), we obtain the differential equation of the heat buildup in the surface element on the tank dry shell under the thermal effect of the fire

$$
\begin{gathered}
\frac{d T_{w}}{d t}=\frac{c_{0} \varepsilon_{s} \varepsilon_{w}}{\rho \delta c}\left[\left(\frac{T_{\hat{o}}}{100}\right)^{4}-\left(\frac{T_{w}}{100}\right)^{4}\right] \psi+ \\
+\frac{c_{0} \varepsilon_{w}}{\rho \delta c}\left[\left(\frac{T_{0}}{100}\right)^{4}-\left(\frac{T_{w}}{100}\right)^{4}\right](1-\psi)+\frac{\alpha_{2}\left(T_{f}-T_{w}\right)}{\rho \delta c}+ \\
+\frac{c_{0} \varepsilon_{w}^{2}}{\rho \delta c}\left[\left(\frac{T_{0}}{100}\right)^{4}-\left(\frac{T_{w}}{100}\right)^{4}\right]+\frac{\alpha_{5}\left(T_{0}-T_{w}\right)}{\rho \delta c},
\end{gathered}
$$

with the initial condition

$$
T_{w}(0)=T_{0} .
$$

Let us note that the location and size of the spill, as well as the direction and speed of the wind affect the parameter values of $\psi, \alpha_{2}$.

Let us denote the spill area of the combustible liquid in the dike as $\Omega$. The height of the flame at an arbitrary point of the spill $(x, y) \in \Omega$ will be equal to [13]

$$
z(x, y)=r \cdot c
$$

where $r$ is the distance from the point $(x, y) \in \Omega$ to the spill boundary $\partial \Omega ; c$ is a constant depending on the type of the fuel: $c=2.8$ for flammable liquids and $c=2.4$ for combustible liquids.

This allows us to express the radiating surface of the flame in a parametric form [13]

$$
\left\{\begin{array}{l}
x=u+r \cdot c \cdot \sin \alpha \cdot \cos \varphi \\
y=v+r \cdot c \cdot \sin \alpha \cdot \sin \varphi, \\
z=r \cdot c \cdot \cos \alpha
\end{array}\right.
$$

where $(u, v) \in \Omega ; r$ is the distance from the point $(u, v)$ to the spill boundary $\partial \Omega$; $(\cos \varphi, \sin \varphi)$ is the vector defining the wind direction; $\alpha$ is the angle at which the flame deviates from the vertical under the influence of the wind [7]. It can be expressed as

$$
\alpha=\operatorname{arctg} \frac{w}{2}
$$

for wind velocity in the range $w \leq 10 \mathrm{~m} / \mathrm{s}$ [13].

Parametric description of the radiating surface of the flame allows expressing its unit normal vector in the following form

$$
\vec{n}=\frac{1}{\sqrt{A^{2}+B^{2}+C^{2}}}(A, B, C),
$$

where

$$
\begin{aligned}
& A=\frac{\partial y}{\partial u} \frac{\partial z}{\partial v}-\frac{\partial z}{\partial u} \frac{\partial y}{\partial v} \\
& B=\frac{\partial z}{\partial u} \frac{\partial x}{\partial v}-\frac{\partial x}{\partial u} \frac{\partial z}{\partial v} \\
& C=\frac{\partial x}{\partial u} \frac{\partial y}{\partial v}-\frac{\partial y}{\partial u} \frac{\partial x}{\partial v}
\end{aligned}
$$

Thus, the view factor is

$$
\begin{gathered}
\psi=\frac{1}{\pi} \iint_{\Omega} \frac{\left[A\left(x-x_{0}\right)+B\left(y-y_{0}\right)+C\left(z-z_{0}\right)\right]}{\left[\left(x-x_{0}\right)^{2}+\left(y-y_{0}\right)^{2}+\left(z-z_{0}\right)^{2}\right]^{2}} \times \\
\times \frac{\left[x_{0}\left(x-x_{0}\right)+y_{0}\left(y-y_{0}\right)\right]}{\sqrt{x_{0}^{2}+y_{0}^{2}}} d u d v,
\end{gathered}
$$

where $\left(x_{0}, y_{0}, z_{0}\right)$ is a point on the tank surface; $(x, y, z)$ is a point on the radiating surface of the flame, which is specified in the parametric form $(13) ; x(u, v)=y(u, v)=$ $z(u, v)=0$, if $(u, v) \notin \Omega$; integration is carried out only 
for the part of the area $\Omega$, in which each of the multipliers in the numerator is positive

$$
\begin{gathered}
A\left(x-x_{0}\right)+B\left(y-y_{0}\right)+C\left(z-z_{0}\right)>0 ; \\
x_{0}\left(x-x_{0}\right)+y_{0}\left(y-y_{0}\right)>0 .
\end{gathered}
$$

The value of the convective heat transfer coefficient $\alpha_{5}$ can be determined from the expression for the Nusselt number $(\mathrm{Nu})[14]$

$$
\alpha_{5}=\frac{N u \lambda_{f}}{L},
$$

where $\lambda_{f}$ is the thermal conductivity coefficient of the vapor-air mixture in the gas space of the tank, which we take as equal to the air thermal conductivity; $L$ is the typical size.

Since the convective heat transfer is free, the $\mathrm{Nu}$ value can be determined from the expression [14]

$$
N u=0.135(G r \cdot \operatorname{Pr})^{1 / 3},
$$

where $G r$ is the Grashof number

$$
G r=\frac{\beta \Delta T L^{3} g}{v^{2}},
$$

where $\Delta T=T_{w}-T_{0} ; \beta$ is the temperature coefficient of the air volumetric expansion, $\beta=1 / T_{w}$; $g$ is the acceleration of gravity; $v$ is the air kinematic viscosity; $\operatorname{Pr} \approx 0.7$ is the Prandtl number of air. Substituting $(16,17)$ into (15), we obtain an estimate of the convective heat transfer coefficient of the tank shell with the vapor-air mixture in the gas space of the tank

$$
\begin{gathered}
\alpha_{5}=0.135(G r \cdot \operatorname{Pr})^{1 / 3} \frac{\lambda_{f}}{L}=0.135\left(\frac{\Delta T L^{3} g}{T_{w} v^{2}} \cdot \operatorname{Pr}\right)^{1 / 3} \frac{\lambda_{f}}{L}= \\
=0.135 \lambda_{f}\left(\frac{g \operatorname{Pr}}{T_{w} v^{2}}\right)^{1 / 3}\left(T_{w}-T_{0}\right)^{1 / 3} .
\end{gathered}
$$

For the forced convective heat transfer (from the plume over the combustion), the Nu value can be estimated from the expression [14]

$$
N u=0.0364 \operatorname{Re}^{0.8} \operatorname{Pr}^{0.4} \varepsilon_{t},
$$

where $\operatorname{Re}=w L / v$ is the Reynolds number; $w$ is the velocity of the air flow in contact with the area $\Delta ; \varepsilon_{t}$ is the adjustment factor

$$
\varepsilon_{t}=\left\{\begin{array}{ll}
\left(\mu_{f} / \mu_{w}\right)^{0.11}, & T_{w}<T_{f} \\
\left(\mu_{f} / \mu_{w}\right)^{0.25}, & T_{w}>T_{f}
\end{array},\right.
$$

where $\mu_{f}, \mu_{w}$ is the air dynamic viscosity at temperatures $T_{f}$ and $T_{w}$ respectively, which is related to the kinematic viscosity $v$ through the expression

$$
\mu=v \rho,
$$

where $\rho$ is the air density. Thus, the estimation of the convective heat transfer coefficient with fire plume takes the following form $\alpha_{2}=\lambda \frac{0.0364(w L)^{0.8} \operatorname{Pr}^{0.4} \varepsilon_{t}}{L v^{0.8}}=\frac{0.0364 \lambda w^{0.8} \operatorname{Pr}^{0.4} \varepsilon_{t}}{L^{0.2} v^{0.8}}$.

Assessments of the speed $w$ and temperature $T_{f}$ of the plume flows over the combustion contained in expressions $(10,19)$ is presented in [15].

As a use case of the above model, let us consider the combustion of a gasoline spill within the dike of the RVS-10000 tank (diameter $34.2 \mathrm{~m}$, height $12 \mathrm{~m}$, capacity $10^{4} \mathrm{~m}$ ), filled with the fuel to the level of $5 \mathrm{~m}-$ Fig. 2 .

Fig. 3 shows the dynamics of the temperature change of the tank shell part facing the fire, whereas Fig. 4 shows the temperature distribution along the circumference of the tank shell, 15 minutes after the start of the fire.

The analysis of the plot in Fig. 3 indicates that the dangerous temperature of $250{ }^{\circ} \mathrm{C}$ (the ignition point of crude oil and some petroleum products) is reached on the side of the tank, facing the flame 2 minutes after the start of the fire. This means that this part of the tank shell needs to be cooled. Fig. 4 shows which parts need to be cooled, i. e. the segment of about $60^{\circ}$ (Fig. 2). And the cooling should begin no later than 2 minutes from the start of the fire in order to prevent the temperature of the steel tank shell from reaching dangerous values.

The results of calculations of vertical temperature distribution on the tank shell part facing the fire have

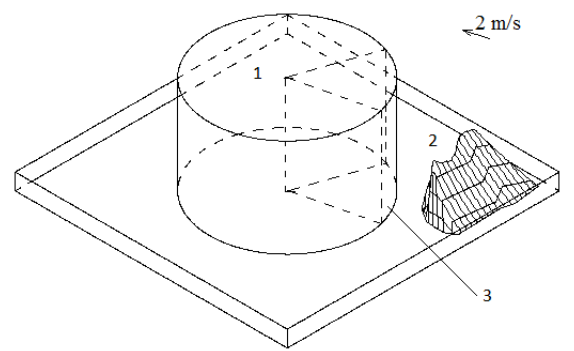

Fig. 2. Burning gasoline spill within the dike of the RVS10000 tank:

1 - tank; 2 - flame above the spill; 3 - part of the tank shell to be cooled

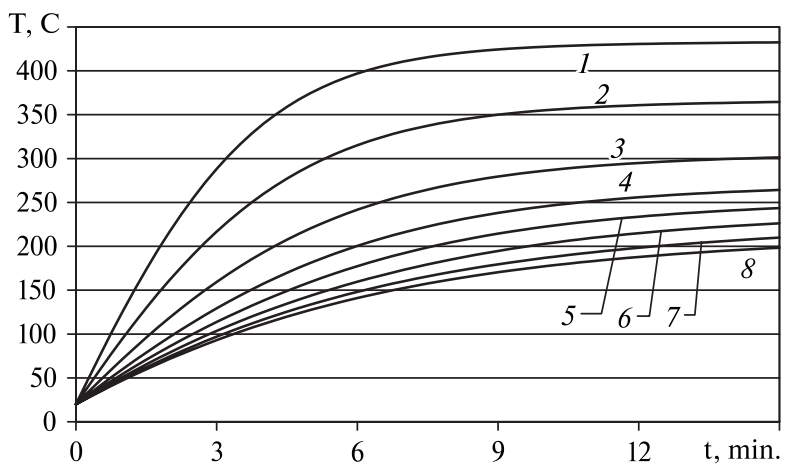

Fig. 3. Dynamics of temperature change of the tank dry shell facing the fire, depending on the height above the ground level:

$1-6 m ; 2-7.5 m ; 3-9 m ; 4-10.5 m ; 5-12 m ; 6-$ $13.5 m ; 7-15 m ; 8-16.5 m$

ISSN 2071-2227, Naukovyi Visnyk NHU, 2018, № 2 
been compared according to the model (10), which takes into account the effect of the plume from the combustion, and to the model [9], which does not take into account such effect, showing (Fig. 5) that the latter may produce an error of up to $20 \%$.

Moreover, the closer the spill is to the tank and the higher the point whose temperature is studied, is on the shell, the greater this error will be.

Conclusions and recommendations for further research. A model has been built for the thermal effect of the pool fire of a combustible liquid spill within a tank dike of the tank containing a petroleum product. The model takes into account both radiant and convective heat transfer of the fire to the tank and the environment. It has been shown that if the convective flows from the heated combustion plume are not taken into account, it can lead to a $20 \%$ error in the assessment of the temperature distribution along the tank shell.

The obtained expressions can be useful for the development of fire pre-plans at the oil refining facilities, design of oil depot protection systems, outlining of zones for safe positioning of the equipment and personnel in-

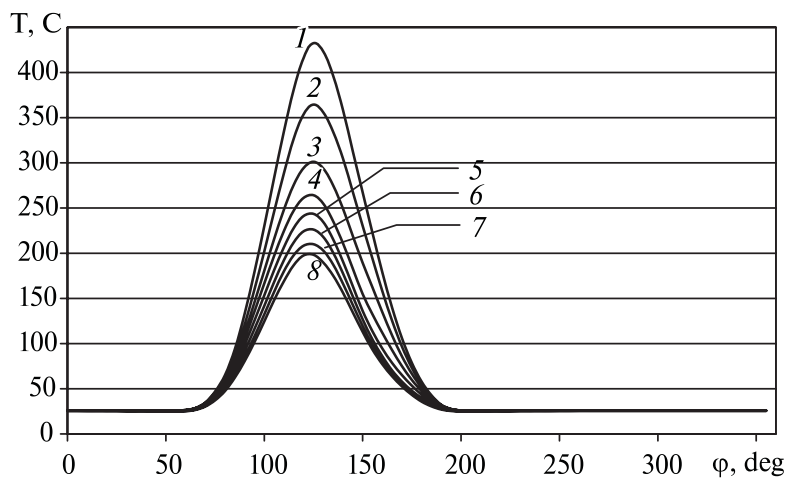

Fig. 4. Circumferential distribution of temperatures on the tank shell, depending on the height above the ground level:

$1-6 m ; 2-7.5 m ; 3-9 m ; 4-10.5 m ; 5-12 m ; 6-$ $13.5 m ; 7-15 m ; 8-16.5 m$

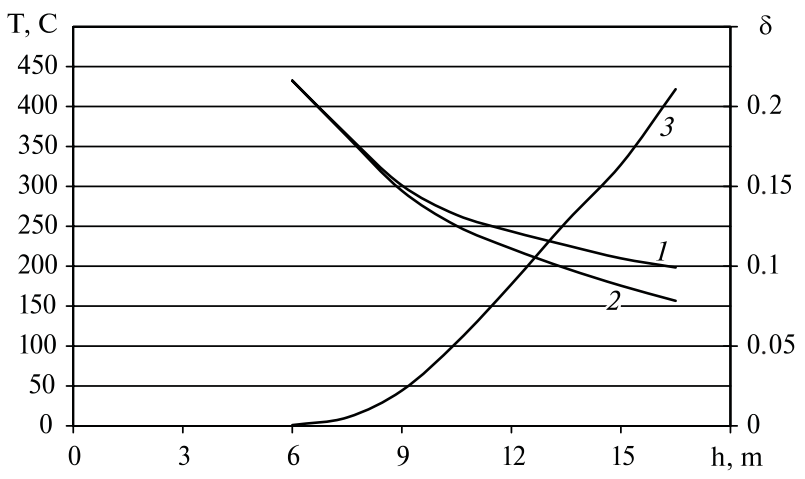

Fig. 5. Vertical distribution of temperatures on the tank shell facing the fire:

1 - taking into account convective flows from the combustion; 2 - without convection flows; 3 - relative error (on the right axis) volved in fire-fighting, as well as for the design of early fire detection systems [16].

\section{References.}

1. Sjostrom, J., Amon, F., Appel, G. and Persson, H., 2015. Thermal exposure from large scale ethanol fuel pool fires. Fire Safety Journal, 78, pp. 229-237.

2. Ditch, B. D., Ris, J. L., Blanchat, T. K. and Chaos, M., 2013. Pool fires - An empirical correlation. Combustion and Flame, 160(12), pp. 2964-2974.

3. Sudheer, S., Kumar, L. and Manjunath, B. S., 2013. Fire safety distances for open pool fires. Infrared Physics \& Technology, 61, pp. 265-273.

4. Sobolev, V.V. and Usherenko, S. M., 2006. Shockwave initiation of nuclear transmutation of chemical elements. Journal de Physique IV (Proceedings), 134, pp. 977-982. DOI:10.1051/jp4:2006134149.

5. Falshtyns'kyy, V., Dychkovs'kyy, R., Lozyns'kyy, V. and Saik, P., 2013. Justification of the gasification channel length in underground gas generator. Annual Scientific-Technical Colletion - Mining of Mineral Deposits, pp. 125-132. DOI:10.1201/b16354-23.

6. Jinlong, Zh., Hong, H., Grunde, J., Maohua, Zh. and Yuntao, L., 2017. Spread and burning behavior of continuous spill fires. Fire Safety Journal, 91, pp. 347-354.

7. Abramov, Yu.A. and Basmanov, A. E., 2005. Fire impact on the oil tank. Vestnik Kharkovskogo natsionalnogo avtomobilno-dorozhnogo universiteta [pdf], 29, pp. 131-133. Available at: <http://repositsc.nuczu.edu.ua/bitstream/ 123456789/283/1/vliyanie-pozhara-na-rezervuar-s-nefteproduktom.pdf> [Accessed 14 March 2017].

8. Chernetskyi, V. V., Semerak, M. M. and Mykhaylyshyn, M. R., 2015. Mathematical modeling and investigating the thermal processes in vertical steel tanks under fire. Pozhezhna bezpeka, 27, pp. 151-157.

9. Ulinets, E. M., 2008. Mathematical model of thermal impact of oil spill fire on tank, Problemy pozharnoj bezopasnosti [pdf], 24, pp. 27-31. Available at: <http://nuczu.edu.ua/sciencearchive/ProblemsOfFireSafety/ vol24/ulinec.pdf> [Accessed 27 May 2017].

10. Lackman, T. and Hallberg, M., 2016. A dynamic heat transfer model to predict the thermal response of a tank exposed to a pool fire. Chemical engineering transactions, 48, pp. 157-162.

11. The Ukrainian Fire Safety Research Institute of the MES of Ukraine, 2004. Instruction for Extinguishing Fires in the Oil Tank Storages. NAPB 05.02: Official edition [pdf]. Available at: <http://univer.nuczu.edu.ua/ tmp_metod/950/Nafta-Instrukcia8S.pdf $>$ [Accessed 9 May 2017].

12. McGrattan, K. B., Walton, D. B. and Evans, D. D., Smoke plumes from in-situ burning of crude oil, In: Proceeding of the International oil spill conference [online], pp. 137-147. Available at: <http://ws680.nist.gov/ publication/get_pdf.cfm?pub_id=911186> [Accessed 11 December 2016].

13. Ulinets, E. M., 2008. Mathematical model of the fire surface above the oil spill in the tank dike. Problemy pozharnoj bezopasnosti [pdf], 23, pp. 37-41. Available at: $<$ http://repositsc.nuczu.edu.ua/bitstream/123456789/ 5254/1/Ulinets.pdf> [Accessed 7 May 2017]. 
14. Sharshanov, A. Ya. and Riabova, I. B., 2013. Thermodynamics and heat transfer in civil safety. Kharkiv: NUCPU.

15. Basmanov, A. E. and Kulik, Ya. S., 2013. Evaluation parameters of thermal flow rising above a flaming spill of arbitrary form. Problemy pozharnoj bezopasnosti, 33, pp. $17-21$.

16. Andronov, V., Pospelov, B. and Rybka, E., 2016. Increase of accuracy of definition of temperature by sensors of fire alarms in real conditions of fire on objects. Eastern-European Journal of Enterprise Technologies, 4-5(82), pp. 38-44.

\section{Модель теплового впливу пожежі в обвалуванні на резервуар з нафтопродуктом \\ Ю. О. Абрамов, О. Е. Басманов, Дж. Саламов, А. О. Михайлюк}

Національний університет цивільного захисту України, м. Харків, Україна, e-mail: alksey.basmanov@nuczu.edu.ua; mihayluk.nuczu@gmail.com

Мета. Побудова математичної моделі нагріву стінки резервуара з нафтопродуктом під тепловим впливом пожежі горючої рідини, розлитої в обвалуванні резервуара.

Методика. Побудовано рівняння теплового балансу для стінки резервуара з нафтопродуктом, що нагрівається під впливом пожежі. Ураховано як променевий, так і конвекційний теплообмін з пожежею й навколишнім середовищем. Для врахування конвекційної складової теплового потоку від пожежі горючої рідини використані оцінки розподілу температур і швидкостей у висхідних потоках над осередком горіння.

Результати. Отримана динаміка зміни температури стінки резервуара з часом під тепловим впливом пожежі горючої рідини в обвалуванні цього резервуара. Отримана залежність є розв'язком диференціального рівняння, побудованого на підставі аналізу теплового балансу для стінки резервуара, що нагрівається.

Наукова новизна. Полягає у врахуванні конвекційної складової теплового потоку від осередку горіння до резервуара 3 нафтопродуктом і побудові оцінок розподілу температур і швидкостей у конвекційному потоці, що утворений пожежею розлитої горючої рідини.

Практична значимість. Запропонована модель нагріву резервуара від пожежі в обвалуванні є основою для побудови системи підтримки прийняття рішення керівником гасіння пожежі, визначення безпечних зон розташування сил і засобів, задіяних у гасінні пожежі, при розробці карток пожежогасіння на об'єктах нафтопереробного комплексу, а також при проектуванні систем захисту резервуарів із нафтопродуктами.
Ключові слова: пожежа розливу, резервуар із нафтопродуктом, обвалування, горюча рідина, теплопередача, конвекція

\section{Модель теплового воздействия пожара} в обваловании на резервуар с нефтепродуктом

\section{Ю. А. Абрамов, А. Е. Басманов, Дж. Саламов, А. А. Михайлюк}

Национальный университет гражданской защиты Украины, г. Харьков, Украина, e-mail: alksey.basmanov@nuczu. edu.ua; mihayluk.nuczu@gmail.com

Цель. Построение математической модели нагрева стенки резервуара с нефтепродуктом под тепловым воздействием пожара разлива горючей жидкости в обваловании резервуара.

Методика. Построено уравнение теплового баланса для стенки резервуара с нефтепродуктом, нагревающейся под воздействием пожара. Учтен как лучистый, так и конвективный теплообмен с пожаром и окружающей средой. Для учета конвективной составляющей теплового потока от пожара горючей жидкости использована оценка распределения температур и скоростей в восходящих потоках над очагом горения.

Результаты. Получена динамика изменения температуры стенки резервуара во времени под тепловым воздействием пожара горючей жидкости в обваловании этого резервуара. Полученная зависимость представляет собой решение дифференциального уравнения, построенного на основании анализа теплового баланса для нагревающейся стенки резервуара.

Научная новизна. Состоит в учете конвективной составляющей теплового потока от очага горения $\mathrm{K}$ резервуару с нефтепродуктом и построении оценок распределения температур и скоростей в конвективном потоке, образованном пожаром разлива горючей жидкости.

Практическая значимость. Предложенная модель нагрева резервуара от пожара в обваловании является основой для построения системы поддержки принятия решения руководителем тушения пожара, определения безопасных зон для размещения сил и средств, задействованных в тушении пожара, при разработке карточек пожаротушения на объектах нефтеперерабатывающего комплекса, а также при проектировании систем защиты резервуаров с нефтепродуктами.

Ключевые слова: пожар разлива, резервуар с нефтепродуктом, обвалование, горючая жидкость, теплопередача, конвекция

Рекомендовано до публікації докт. техн. наук О.А.Тарасенком. Дата надходження рукопису 14.02.17. 